\title{
EFEKTIVITAS STRATEGI KOMUNIKASI PEMASARAN SOSIAL KAMPANYE SUSTAINABLE SEAFOOD, WWF-INDONESIA
}

\section{(Effectiveness of Social Marketing Sustainable Seafood Campaign Coomunication Strategy by WWF Indonesia)}

\author{
Riski Bayuni Sagala ${ }^{1)}$ dan Yatri Indah Kusumastuti ${ }^{1)}$ \\ ${ }^{1)}$ Departemen Sains Komunikasi dan Pengembangan Masyarakat, Fakultas Ekologi Manusia, \\ Institut Pertanian Bogor, Darmaga Bogor 16680, Indonesia \\ Email: riskibayunisagala@gmail.com; yatri.kusumastuti@apps.ipb.ac.id
}

\begin{abstract}
Social marketing communication strategy is a tool used by the company to achieve its goal. The effectiveness of social marketing communication strategy can be seen from the change in the attitude of the campaign target refers to the cognitive, affective, and conative. The purpose of this study was to analyze the social marketing communication strategy undertaken by WWF in running campaigns, analyze the effectiveness of social marketing communications conducted by WWF in running his campaign, and analyze correlation between strategy of social marketing and effectiveness of social marketing communications conducted by WWF in running his campaign. The method used in this research was supported by survey method with quantitative and qualitative data. In this research, social marketing communication strategy under study is a social marketing communication strategy Campaign Sustainable Seafood, WWF-Indonesia. The results showed the dominance of media used by the respondent to get a message is a media meeting and the relationship between social marketing communication strategy and media exposure frequency of the effectiveness of social marketing communication strategy on aspect of cognitive, affective, and conative.
\end{abstract}

Keywords: attitude change, strategy, media exposure

\begin{abstract}
ABSTRAK
Strategi komunikasi pemasaran sosial adalah alat yang digunakan oleh perusahaan untuk mencapai tujuannya. Efektivitas strategi komunikasi pemasaran sosial dapat dilihat dari perubahan sikap target kampanye pada kognitif, afektif, dan konatif. Tujuan dari penelitian ini adalah untuk menganalisis strategi komunikasi pemasaran sosial yang dilakukan oleh WWF dalam menjalankan kampanye, menganalisis efektivitas komunikasi pemasaran sosial yang dilakukan oleh WWF dalam menjalankan kampanyenya, dan menganalisis hubungan antara strategi pemasaran sosial dan efektivitas komunikasi pemasaran sosial yang dilakukan oleh WWF dalam menjalankan kampanyenya. Metode yang digunakan dalam penelitian ini didukung oleh metode survei dengan data kuantitatif dan kualitatif. Dalam penelitian ini, strategi komunikasi pemasaran sosial yang diteliti adalah strategi komunikasi Kampanye Sustainable Seafood, WWF-Indonesia. Hasil penelitian menunjukkan dominasi media yang digunakan oleh responden untuk mendapatkan pesan adalah pertemuan media dan hubungan antara strategi komunikasi pemasaran sosial dan frekuensi keterdedahan media dari efektivitas strategi komunikasi pemasaran sosial pada aspek kognitif, afektif, dan konatif.
\end{abstract}

Kata kunci: perubahan sikap, strategi, keterdedahan media

\section{PENDAHULUAN}

Terdapat sekitar 60 juta penduduk Indonesia yang tinggal di wilayah pesisir dan menyumbang sekitar 22 persen dari pendapatan bruto nasional. Hal tersebut menunjukkan bahwa prospek pembangunan perikanan dan kelautan Indonesia menjadi salah satu kegiatan ekonomi yang strategis. Selain itu sumberdaya ikan di wilayah perairan Indonesia yang kurang lebih mencakup 73 persen dari spesies ikan di dunia (Kantor Menteri Negara Lingkungan Hidup, 1994).

Namun, beberapa wilayah pengelolaan perikanan di Indonesia sudah menghadapi 
gejala eksploitasi ikan berlebihan (overfishing) untuk beberapa kelompok komoditas penting, seperti pelagis besar, pelagis kecil, udang, dan ikan demersal. Dalam rangka mengelola perikanan, pada 3 Agustus 2011 dikeluarkan Keputusan Menteri Kelautan dan Perikanan (Kepmen KP) Nomor Kep. 45/Men/2011 Data menunjukkan produksi tangkapan laut sudah menembus angka 82 persen melebihi pemanfaatan optimal yang disyaratkan sebesar 80 persen.

Dilandasi oleh hal itu, dewasa ini muncul usaha-usaha menjaga lingkungan hidup, khususnya perairan Indonesia yang disuarakan baik oleh pemerintah maupun Lembaga Swadaya Masyarakat (LSM) yang bergerak dibidang lingkungan. Dalam menyuarakan gerakan menjaga lingkungan, tak jarang pemerintah atau LSM menggunakan strategi komunikasi pemasaran sosial. Pemasaran sosial menurut Kotler dan Zaltman (1981) merupakan a strategy for changing behavior. It combines the best elements of the traditional approaches to social change in an integrated planning and action framework and utilizes advances in communication technology and marketing skills. Pemasaran sosial menyampaikan pesanpesan sosial dengan melibatkan pertimbangan perencanaan produk, harga, komunikasi, distribusi, dan riset pemasaran.

Pemasaran sosial menggunakan komunikasi pemasaran sosial sebagai alat untuk mencapai tujuan dalam penyampaian pesannya. Salah satu upaya pemerintah maupun LSM dalam melakukan komunikasi pemasaran sosial adalah melalui kampanye. Pfau dan Parrot dalam Venus (2004) menyatakan bahwa kampanye adalah suatu proses yang dirancang secara sadar, bertahap, dan berkelanjutan yang dilaksanakan pada rentang waktu tertentu dengan tujuan mempengaruhi khalayak sasaran yang telah ditetapkan. Kegiatan kampanye dapat dilakukan lewat berbagai media.

Kegiatan kampanye sering digambarkan memiliki peranan penting dalam penyampaian pesan kepada khalayak dan memerlukan strategi komunikasi pemasaran sosial dalam kegiatan kampanye. Tull dan Kahle dalam Tjiptono (2008) mendefinisikan strategi pemasaran sebagai alat fundamental yang direncanakan untuk mencapai tujuan perusahaan dengan mengembangkan keunggulan bersaing yang berkesinambungan melalui pasar yang dimasuki dan program pemasaran yang digunakan untuk melayani pasar sasaran tersebut.

Salah satu kampanye yang menggunakan strategi komunikasi pemasaran sosial adalah kampanye Sustainable Seafood yang diusung oleh World Wide Fund for Nature (WWF) dimulai pada tahun 2011. Kegiatan kampanye ini bertujuan untuk menjaga stok ikan dan meningkatkan mutu lingkungannya dan membangun komitmen para aktor industri perikanan (nelayan, konsumen, dan perusahaan). Salah satu bentuk strategi komunikasi pemasaran sosialnya adalah dengan pembuatan seafood guide dan penggunaan media internet.

Berdasarkan latar belakang tersebut, menarik untuk diteliti:

1. Bagaimana strategi komunikasi pemasaran sosial yang dilakukan oleh WWF dalam menjalankan kampanyenya?

2. Bagaimana efektivitas komunikasi pemasaran sosial yang dilakukan oleh WWF dalam menjalankan kampanyenya?

3. Bagaimana hubungan strategi komunikasi pemasaran sosial dengan efektivitas strategi komunikasi pemasaran sosial?

\section{PENDEKATAN TEORITIS}

\section{Komunikasi Pemasaran Sosial}

Komunikasi memiliki peran menurut Shimp (2003a) dalam proses pemikiran dan pemahaman yang disampaikan antarindividu atau antara organisasi dengan individu. Menurut Black dan Bryant dalam Lubis (2009) komunikasi merupakan proses di mana seorang komunikator mengirimkan pesan untuk mengubah perilaku komunikan. Komunikasi memiliki beberapa unsur, meliputi:

1. Sumber, yaitu orang atau sekelompok orang yang sengaja dan bertujuan untuk berkomunikasi. Sumber merupakan orang yang mengirimkan pesan.

2. Penerima, yaitu orang atau sekelompok orang pada sisi lain proses komunikasi. Dalam hal ini penerima merupakan orang 
yang menerima pesan yang disampaikan oleh sumber.

3. Pesan, yaitu sesuatu yang dikirimkan oleh sumber kepada penerima.

4. Saluran, saluran komunikasi mencakup tiga pengertian, yaitu moda membuat kode (encoding) dan menerjemah kode (decoding) dari pesan, kendaraan pesan (messaage vechicle), dan pembawa pesan (message carrier). Saluran dapat dikatakan sebagai media perantara yang membawa pesan dari sumber kepada penerima.

5. Akibat, hasil komunikasi atau respons penerima terhadap pesan yang disampaikan oleh sumber.

6. Umpan balik, yaitu respons penerima yang diterima oleh sumber.

Perusahaan non profit menggunakan komunikasi pemasaran untuk menyampaikan pesan dengan tujuan merubah perilaku konsumen. Manfaat komunikasi dalam pemasaran Rasmuson et al. (1988) adalah untuk meningkatkan kesadaran akan masalah-masalah sosial, mempengaruhi sikap yang pada tahap selanjutnya akan mendorong perubahan perilaku sikap baik individu maupun kolektif, dan memperkuat pengetahuan, sikap, dan perilaku.

\section{Strategi Komunikasi Pemasaran Sosial}

Strategi pemasaran sosial dalam mengkomunikasikan kampanye sosialnya menurut Ruslan (2005) dapat diuraikan sebagai berikut:

a. Sebagai komunikator, harus mampu menjelaskan atau menyampaikan sesuatu kegiatan atau aktivitas dan program kerja kepada publiknya, sekaligus ia bertindak sebagai modiator untuk mewakili lembaga atau organisasi terhadap publik dan sebaliknya.

b. Pesan atau message merupakan sesuatu yang perlu disampaikan kepada penerima melalui teknik kampanye tertentu berupa ide, gagasan, informasi, aktivitas, atau kegiatan tertentu yang dipublikasikan atau dipromosi-kan untuk diketahui, dipahami, dan dimengerti yang sekaligus diterima oleh publiknya.

c. Media merupakan sarana atau alat untuk menyampaikan pesan atau sebagai mediator antara komunikator dengan komunikan. Media atau alat kampanye dapat digolongkan sebagai berikut:

- Media umum, seperti surat menyurat, telepon, faksimili, dan telegraf.

- Media massa, seperti media cetak dan media elektronik.

- Media internal, yaitu media yang dipergunakan untuk kepentingan kalangan terbatas dan nonkomersil serta kepentingan kalangan terbatas dan nonkomersil serta lazim dipergunakan dalam aktivitas kampanye. Media ini terdapat beberapa jenis, yaitu house journal seperti majalah bulanan, buletin, dan tabloid. Printed materials seperti barang cetakan untuk publikasi dan promosi, berupa booklet, pamphlet, dan leaflet. Spoken and visual word, seperti audio visual, slide film, dan media perlengkapan radio dan televisi.

- Media pertemuan, seperti seminar, pameran, diskusi, presentasi, dan gathering meet.

d. Komunikan, yakni publik yang menjadi sasaran dalam komunikasi secara langsung atau tidak. Secara langsung atau tatap muka dapat diklasifikasikan menjadi komunikasi antar-personal, komunikasi kelompok, dan komunikasi media massa.

Tujuan komunikasi dalam kampanye menurut Ruslan (2005) untuk mempromosikan dan mempublikasi-kan pesan kepada sasaran. Pemasaran bertujuan menciptakan pengetahuan, pengertian, pemahaman, kesadaran, minat, dan dukungan dari berbagai pihak. Strategi dalam komunikasi pemasaran sosial merupakan suatu perencanaan dan manajemen untuk mencapai tujuan tertentu dalam praktik operasionalnya.

\section{Kampanye}

Rogers dan Storey dalam Venus (2004) kampanye adalah serangkaian tindakan komunikasi yang terencana dengan tujuan menciptakan efek tertentu pada sejumlah besar khalayak yang dilakukan secara berkelanjutan pada kurun waktu tertentu. Kegiatan kampanye selalu terkait dengan aspek pengetahuan, sikap, dan perilaku Pfau dan Parrot dalam Venus (2004). Ketiga aspek tersebut terkait dan 
merupakan sasaran yang dicapai secara bertahap.

\section{Efektivitas Komunikasi Pemasaran Sosial}

Efektivitas komunikasi pemasaran sosial dapat dilihat dari perubahan sikap sasaran. Severin dan Tankard (2005) menyatakan sikap merupakan rangkuman evaluasi terhadap objek sikap di mana evaluasi rangkuman rasa suka atau tidak suka terhadap objek sikap adalah inti dari sikap. Efek atau respon konsumen menurut Tjiptono (2008) dapat dilihat dari sebagai berikut:

a. Efek kognitif ialah membentuk kesadaran informasi tertentu. Dampak kognitif yang timbul pada komunikasi yang menyebabkan komunikan menjadi tahu atau meningkatkan intelektualitasnya. Di sini pesan yang disampaikan komunikator ditujukan kepada pemikiran komunikan. Tujuan komunikator hanyalah berkisar pada upaya mengubah pikiran si komunikan.

b. Efek afektif ialah memberikan pengaruh untuk melakukan sesuatu. Tujuan komunikator bukan hanya sekedar supaya komunikan tahu, tetapi tergerak hatinya dan menimbulkan perasaan tertentu.

c. Efek konatif yaitu membentuk pola khalayak menjadi perilaku selanjutnya. Efek pada konatif berhubungan dengan perilaku dan niat untuk melakukan sesuatu dengan cara tertentu.

Menurut Shimp (2003b) aspek kognitif mengacu pada pemikiran dan pengetahuan mengenai suatu objek atau permasalahan tertentu, aspek afektif memfokuskan pada perasaan dan aspek konatif memiliki kecenderungan untuk melakukan tindakan atas sebuah objek. Dari ketiga aspek tersebut terlihat adanya kemajuan bermula dari aspek kognitif, aspek afeksi, kemudian aspek konatif. Bermula dari individu yang mulai sadar akan sebuah obyek, kemudian memperoleh informasi dan membentuk kepercayaan mengenai kemampuan obyek tersebut (komponen kognitif). Setelah kepercayaan terbentuk, perasaan dan, dan evaluasi atas produk tersebut dikembangkan (komponen afektif) dan timbul suatu niat untuk mengikuti pesan dalam pemasaran tersebut atau tidak mengikuti pesan tersebut (komponen konatif).

\section{Kerangka Pemikiran}

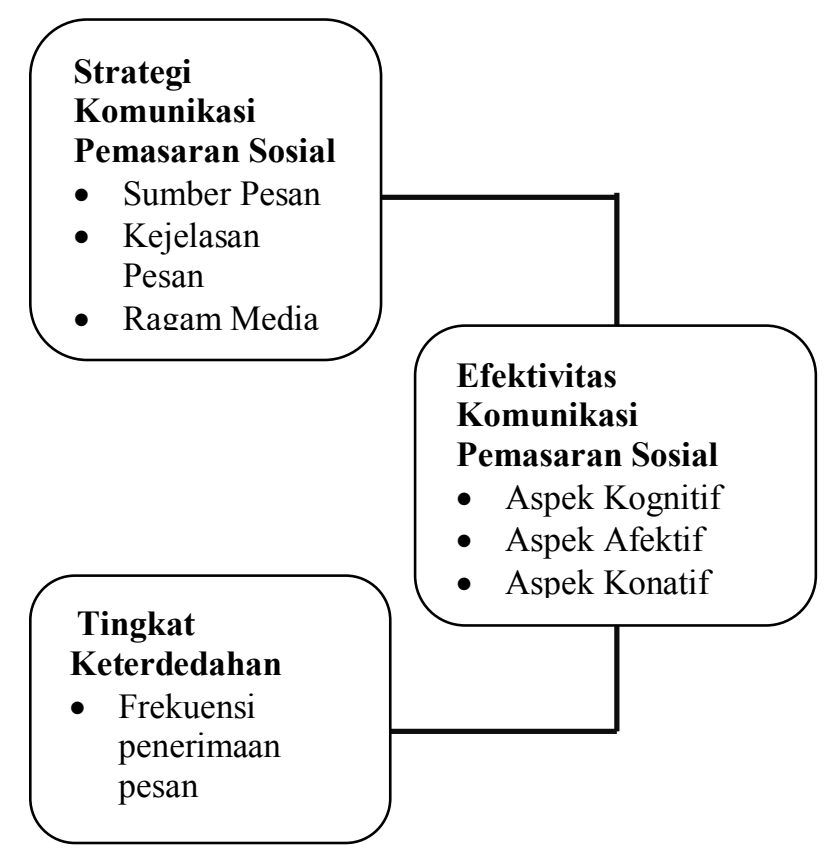

Keterangan:

\section{— : Berhubungan}

Gambar 1. Kerangka penelitian

Kegiatan kampanye dalam menyampaikan pesan dan memperkenalkan kegiatan kampanye pada masyarakat membutuhkan strategi komunikasi pemasaran sosial komunikasi pemasaran sosial berupa sumber pesan, pesan, dan ragam media. Bukan hanya strategi komunikasi pemasaran sosial dan karakteristik responden yang memiliki hubungan dengan efektivitas komunikasi pemasaran sosial, tetapi juga tingkat keterdedahan yang dilihat dari frekuensi penerimaan pesan juga memiliki hubungan dengan efektivitas komunikasi pemasaran sosial. Efektivitas komunikasi pemasaran sosial dapat diukur dari tiga komponen, yaitu kognitif, afektif, dan konatif.

\section{Hipotesis Penelitian}

Hipotesis penelitian ini yaitu:

1. Terdapat hubungan antara strategi komunikasi pemasaran dengan efektivitas komunikasi pemasaran sosial.

2. Terdapat hubungan antara tingkat keterdedahan dengan efektivitas komunikasi pemasaran sosial. 


\section{METODE PENELITIAN}

Metode yang digunakan pada penelitian ini adalah metode penelitian kuantitatif dan didukung dengan data kualitatif untuk memperkaya analisis. Metode penelitian kuantitatif yang digunakan adalah penelitian survai, yaitu penelitian yang mengambil sampel dari suatu populasi dan menggunakan kuesioner sebagai alat pengumpul data primer (Singarimbun dan Effendi 2008). Unit analisis dalam penelitian ini adalah individu. Penentuan lokasi untuk penelitian ini dilakukan secara sengaja (purposive) yaitu di Pemalang, Jawa Tengah. Penelitian ini dilaksanakan dari bulan Mei 2014 sampai dengan Januari 2015. Jumlah responden pada kategori konsumen berjumlah 26 responden dan pada kategori produsen (nelayan) berjumlah 18 responden. Jumlah tersebut didapat berdasarkan penggunaan rumus dalam teknik propotionate stratified random sampling.

Data yang digunakan dalam penelitian ini adalah data primer dan data sekunder. Data primer adalah data yang diperoleh melalui kuesioner dan wawancara dengan informan, yakni pengurus WWF dan LSM aliansi WWF. Kuesioner tersebut dimaksudkan sebagai suatu daftar pertanyaan untuk memperoleh data berupa jawaban-jawaban dari para responden serta ditujukan untuk memperoleh informasi yang relevan dengan tujuan penelitian. Selain wawancara terstruktur menggunakan kuesioner, pengumpulan data penelitian ini juga menggunakan wawancara mendalam dengan pihak dengan penelitian ini. Data kuantitatif yang diperoleh dari kuesioner ditabulasi dengan program Microsoft Excel 2010, kemudian dianalisis secara statistik deskriptif. Hasil analisis diinterpretasikan untuk memperoleh suatu kesimpulan. Data kuantitatif pengurus. Data sekunder yang digunakan dalam penelitian ini diperoleh dari dokumen perusahaan, serta berbagai literatur yang relevan diuji dengan menggunakan uji statistik analisis rank spearman untuk melihat hubungan dan keeratan hubungan dari data-data ordinal. Pengolahan data dilakukan dengan menggunakan program komputer SPSS (Statistical Program for Social Sciences) for Windows version 16.0 untuk mempermudah dalam pengolahan data.

\section{HASIL DAN PEMBAHASAN}

\section{Gambaran Umum Kampanye Sustainable Seafood}

World Wide Fund for Nature atau akrab disebut WWF mengajak masyarakat untuk menghentikan eksploitasi melalui Kampanye Sustainable Seafood. Kampanye Sustainable Seafood berlangsung sejak tahun 2011 dan diadakan di seluruh Indonesia. World Wide Fund for Nature tidak bekerja sendiri dalam melaksanakan Kampanye Sustainable Seafood, WWF bekerja sama dengan 12 LSM.

Tujuan Kampanye Sustainable Seafood yakni untuk meningkatkan permintaan nasional terhadap hidangan laut lestari (sustainable seafood). Prinsip yang diusung oleh WWF dalam Kampanye Sustainable Seafood adalah menjaga stok ikan dan meningkatkan mutu lingkungannya serta membangun komitmen para aktor industri perikanan (nelayan, konsumen, dan perusahaan) dalam menciptakan perilaku dan bisnis perikanan yang berkelanjutan. Sasaran kampanye ini adalah produsen (nelayan), konsumen, dan pebisnis perikanan.

Kampanye Sustainable Seafood memiliki strategi-strategi untuk mencapai tujuannya. Strategi pertama adalah membangun jaringan produsen makanan laut, pembeli, dan pengecer melalui program Seafood Savers, strategi kedua adalah adanya keterlibatan pengecer untuk mempromosikan Seafood Guide kepada konsumen, strategi ketiga adalah melibatkan pemasok dengan mempromosikan BMP (Better Management Practices) untuk berjalan lebih baik praktek perikanan, strategi keempat adalah melakukan serangkaian acara konsultasi publik untuk menekankan isu-isu perikanan dan solusi alternatif terhadap pengelolaan perikanan yang berkelanjutan dengan para pembuat kebijakan, pejabat pemerintah, dan praktisi, strategi selanjutnya adalah memberikan informasi mengenai perikanan di Indonesia dan pentingnya perikanan berkelanjutan melalui media sosial, seperti Twitter dan Facebook, strategi keenam adalah meningkatkan kesadaran tentang isu-isu kelautan melalui perlombaan seperti lomba foto, lomba video, dan lomba blog, strategi kedelapan adalah melibatkan mitra yang berkaitan dengan tujuan dari 
Kampanye Sustainable Seafood seperti bekerja sama dengan LSM-LSM lokal, strategi kesembilan adalah memberikan informasi mengenai hidangan laut lestari kepada masyarakat kelas menengah-atas selaku konsumen agar dapat merubah sikap sesuai dengan tujuan Kampanye Sustainable Seafood dan strategi terakhir adalah membuka pendaftaran bagi masyarakat yang ingin ikut terlibat dalam kegiatan Kampanye Sustainable Seafood. Strategi kesembilan adalah memberikan informasi mengenai hidangan laut lestari kepada masyarakat kelas menengah-atas selaku konsumen agar dapat merubah sikap sesuai dengan tujuan Kampanye Sustainable Seafood dan strategi terakhir adalah membuka pendaftaran bagi masyarakat yang ingin ikut terlibat dalam kegiatan Kampanye Sustainable Seafood, seperti menjadi relawan dan donatur.

\section{Sumber Pesan}

Sumber pesan adalah sumber pesan yang pernah memberikan informasi mengenai Kampanye Sustainable Seafood. Kategori sumber pesan terdiri atas tiga kategori, yakni rendah, sedang, dan tinggi.

Penelitian menunjukkan menunjukkan bahwa pada sumber pesan pada responden kategori konsumen berada dalam kategori rendah yakni sebesar 30.8 persen, sementara responden dalam kategori produsen, berada dalam kategori rendah yakni sebesar 61.1 persen. Mayoritas responden kategori produsen mengaku bahwa komunikator yang menyampaikan informasi mengenai Kampanye Sustainable Seafood didominasi oleh pengurus WWF dan LSM aliansi WWF. Sementara responden kategori konsumen menyatakan bahwa komunikator yang menyampaikan informasi mengenai Kampanye Sustainable Seafood tidak hanya berasal dari pihak WWF dan LSM aliansi WWF saja, melainkan teman dan media sosial. Selain itu penelitian menunjukkan bahwa responden baik kategori konsumen dan produsen berada dalam kategori sedang yakni sebesar 56.8 persen secara keseluruhan. Dapat disimpulkan bahwa responden mendapatkan informasi mengenai Kampanye Sustainable Seafood berasal dari empat sampai enam sumber.

\section{Pesan}

Pesan adalah materi mengenai Kampanye Sustainable Seafood yang disampaikan kepada responden baik responden kategori konsumen maupun produsen dan kesesuaian materi dengan tujuan kampanye yang disampaikan dan kebiasaan responden dalam mengonsumsi makanan laut. Kategori pesan terdiri atas tiga kategori, yakni rendah, sedang, dan tinggi.

Berdasarkan penelitian terlihat bahwa kejelasan pesan yang disampaikan pada responden kategori konsumen berada dalam kategori sedang yakni sebesar 84.6 persen. Mayoritas responden kategori konsumen mengaku bahwa mereka dapat memahami pesan yang disampaikan dan penggunaan bahasa yang digunakan juga dapat dimengerti. Pada responden kategori produsen berada dalam kategori sedang yakni sebesar 72.2 persen. Penelitian menunjukkan bahwa kejelasan pesan baik pada responden kategori konsumen maupun produsen berada dalam kategori sedang yakni sebesar 79.5 persen secara keseluruhan. Dapat disimpulkan, bahwa pesan yang disampaikan kepada responden sudah cukup jelas dan sesuai dengan tujuan kampanye dan kebiasaan yang kerap dilakukan oleh responden.

\section{Ragam Media}

Ragam media komunikasi adalah ragam media yang digunakan untuk menyampaikan pesan dari komunikator kepada komunikan. Kategori ragam media komunikator terdiri atas tiga kategori, yakni rendah, sedang, dan tinggi.

Berdasarkan penelitian terlihat bahwa ragam media komunikasi pada responden kategori konsumen berada dalam kategori sedang yakni 65.4 persen, pada responden kategori konsumen, responden kategori produsen berada dalam kategori rendah yakni 61.1 persen. Mayoritas responden kategori produsen mengaku bahwa mereka jarang menggunakan media untuk mendapatkan informasi mengenai Kampanye Sustainable Seafood. Sementara responden kategori konsumen menyatakan bahwa mereka cukup sering mendapatkan informasi mengenai Kampanye Sustainable Seafood baik dari media sosial maupun 
pameran yang diadakan oleh WWF atau LSM aliansi WWF.

Penelitian menunjukkan bahwa ragam media komunikasi berada dalam kategori rendah dan kategori sedang yakni 47.7 persen secara keseluruhan. Dapat disimpulkan, bahwa jumlah responden yang jarang dan cukup sering menggunakan media komunikasi untuk memperoleh informasi mengenai Kampanye Sustainable Seafood seimbang.

Jenis media yang digunakan dalam kampanye terbagi menjadi empat kategori yakni media umum; surat menyurat, telepon, facsmile, dan telegraf, media massa; media cetak dan media elektronik, media internal; majalah bulanan, buletin, tabloid, booklet, pamphlet, dan leaflet, audio visual, slide film, radio, dan televisi, dan media pertemuan; seminar, pameran, diskusi, presentasi, dan gathering meet. Gambar 2 menunjukkan bahwa jenis media komunikasi yang digunakan oleh responden adalah media pertemuan dengan jumlah persentase sebesar 65.9 persen secara keseluruhan.

\section{Tingkat Keterdedahan Media}

Frekuensi keterdedahan adalah tingkat keseringan responden menerima bentuk pelaksanaan komunikasi pemasaran yang dilakukan oleh WWF mengenai Kampanye Sustainable Seafood dalam kurun waktu satu bulan. Kategori frekuensi keterdedahan media terdiri atas tiga kategori, yakni rendah, sedang, dan tinggi.

Berdasarkan penelitian terlihat bahwa frekuensi keterdedahan pada responden kategori konsumen berada dalam kategori sedang 46.2 persen dan pada responden kategori produsen berada dalam kategori rendah yakni 50.0 persen, sementara 50.0 persen pada kategori sedang. Mayoritas responden kategori produsen mengaku bahwa mereka tidak sering mendapatkan informasi mengenai Kampanye Sustainable Seafood melalui media cetak dan internet. Sementara responden kategori konsumen menyatakan bahwa mereka cukup sering mendapatkan informasi mengenai Kampanye Sustainable Seafood dari media sosial, majalah, leaflet, dan lain sebagainya. Penelitian menunjukkan bahwa frekuensi keterdedahan berada dalam kategori sedang yakni sebesar 47.7 persen secara keseluruhan. Dapat disimpulkan, bahwa responden cukup sering menerima bentuk pelaksanaan komunikasi pemasaran sosial dalam kurun waktu satu bulan.

\section{Efektivitas Komunikasi Pemasaran Sosial}

\section{Aspek Kognitif}

Aspek kognitif adalah pengetahuan responden mengenai Kampanye Sustainable Seafood. Aspek kognitif terdiri atas tiga kategori, yakni rendah, sedang, dan tinggi.

Penelitian memperlihatkan bahwa sebanyak 61.5 persen responden termasuk dalam kategori konsumen termasuk dalam kategori tinggi, sementara pada responden kategori produsen sebanyak 50 persen responden termasuk dalam kategori rendah dan 50 persen termasuk dalam kategori sedang. Hal ini dapat disebabkan oleh rendahnya sumber pesan dan media dalam menyampaikan informasi mengenai Kampanye Sustainable Seafood kepada responden. Berdasarkan penelitian menunjukkan bahwa aspek kognitif responden berada dalam kategori tinggi yakni 56.8 persen secara keseluruhan. Aspek kognitif dalam penelitian ini diperoleh responden melalui informasi dari besumber pesan dan media.

\section{Aspek Afektif}

Aspek afektif adalah perasaan emosi, keinginan, maupun rasa suka dan rasa tidak suka yang dimiliki responden. Aspek kognitif terdiri atas tiga kategori, yakni rendah, sedang, dan tinggi. Efektivitas strategi komunikasi pemasaran pada aspek konatif dapat dilihat pada penelitian. Efektivitas strategi komunikasi pemasaran sosial dilihat dari aspek afektif kategori produsen termasuk dalam kategori sedang yakni sebesar 66.7 dan pada responden kategori konsumen masuk dalam kategori tinggi yakni 53.8 persen. Penelitian menunjukkan bahwa aspek afektif responden berada dalam kategori tinggi yakni 54.5 persen secara keseluruhan. Hasil yang diperoleh pada penelitian memperlihatkan bahwa mayoritas 
responden menyukai dan tertarik terhadap informasi mengenai Kampanye Sustainable Seafood melalui sumber pesan dan media.

\section{Aspek Konatif}

Aspek afektif merupakan tindakan nyata atau perilaku responden untuk melakukan kegiatan sesuai dengan tujuan Kampanye Sustainable Seafood. Aspek konatif terdiri atas tiga kategori yakni rendah, sedang, dan tinggi.

Efektivitas strategi komunikasi pemasaran sosial dilihat dari aspek konatif termasuk dalam kategori tinggi baik pada responden kategori konsumen maupun produsen yakni sebesar 69.2 persen (untuk responden kategori konsumen) dan 50 persen (untuk responden kategori produsen). Penelitian menunjukkan bahwa aspek konatif responden berada dalam kategori tinggi yakni 61.4 persen.

\section{Hubungan Strategi Komunikasi Pemasaran Sosial dengan Efektivitas Komunikasi Pemasaran Sosial}

Hubungan strategi komunikasi pemasaran sosial terhadap efektivitas strategi komunikasi pemasaran adalah hubungan sumber pesan, pesan, dan ragam media yang digunakan dalam menyebarkan informasi mengenai Kampanye Sustainable Seafood, WWF dengan efektivitas strategi komunikasi pemasaran yang dilihat dari tiga aspek yakni aspek kognitif, aspek afektif, dan aspek konatif. Berdasarkan kerangka penelitian yang peneliti gambarkan sebelumnya (Gambar 1) dapat dilihat bahwa terdapat hubungan antara strategi komunikasi pemasaran sosial dengan efektivitas komunikasi pemasaran dalam penelitian pada responden kategori konsumen.

Penelitian memperlihatkan hubungan antara strategi komunikasi pemasaran sosial dengan efektivitas komunikasi pemasaran sosial. Pada penelitian tersebut terlihat bahwa terdapat hubungan yang kuat antara ragam sumber pesan, pesan, dan ragam media terhadap aspek kognitif pada responden kategori konsumen dan ragam sumber pesan dengan aspek konatif. Selain itu terdapat hubungan yang kuat pula antara ragam sumber pesan dengan aspek konatif dan ragam sumber media dengan aspek konatif. Hal tersebut disebabkan oleh responden kategori konsumen yang sudah cukup mendapatkan pesan dengan jelas dari beragam sumber dan beragam media. Beragamnya media dan sumber yang diterima oleh responden kategori konsumen menjadikan konsumen menjadi lebih mengetahui mengenai Kampanye Sustianable Seafood. Hal tersebut mengakibatkan timbulnya dorongan untuk merubah sikap sesuai dengan pesan yang disampaikan ketika mengikuti Kampanye Sustainable Seafood.

Pada penelitian memperlihatkan hubungan antara strategi komunikasi pemasaran sosial dengan efektivitas komunikasi pemasaran sosial pada responden kategori produsen. Pada penelitian tersebut memperlihatkan adanya hubungan kuat antara ragam sumber pesan, pesan, dan ragam media dengan aspek kognitif dan terdapat hubungan yang kuat antara pesan dengan aspek konatif.

Berdasarkan penelitian hubungan antara ragam sumber pesan, pesan, dan ragam media dengan aspek kognitif disebabkan oleh adanya diskusi yang diadakan rutin antara pihak WWF dan atau pihak LSM aliansi WWF dengan responden kategori produsen mengenai Kampanye Sustainable Seafood yang mengakibatkan responden kategori produsen menjadi memahami mengenai materi-materi yang diberikan terkait dengan Kampanye Sustainable Seafood. Hal tersebut mengakibatkan timbulnya dorongan untuk merubah sikap sesuai dengan pesan yang disampaikan.

\section{Hubungan Tingkat Keterdedahan Media dengan Efektivitas Komunikasi Pemasaran Sosial}

Hubungan tingkat keterdedahan responden terhadap efektivitas komunikasi pemasaran adalah hubungan tingkat frekuensi keterdedahan media yang didapat oleh reponden mengenai informasi Kampanye Sustainable Seafood, WWF dengan efektivitas strategi komunikasi pemasaran yang dilihat dari tiga aspek yakni aspek kognitif, aspek afektif, dan aspek konatif. Berdasarkan kerangka 
penelitian yang peneliti gambarkan sebelumnya (Gambar 1) dapat dilihat bahwa terdapat hubungan antara tingkat frekuensi keterdedahan media dengan efektivitas komunikasi pemasaran dalam penelitian pada responden kategori konsumen.

Penelitian memperlihatkan hubungan antara keterdedahan media dengan efektivitas komunikasi pemasaran sosial. Pada penelitian tersebut terlihat bahwa terdapat hubungan yang kuat antara frekuensi keterdedahan media terhadap aspek kognitif dan konatif pada responden kategori konsumen. Hal tersebut disebabkan oleh responden kategori konsumen yang sudah cukup terkena pesan melalui media. Mayoritas media yang digunakan untuk mendapatkan pesan Kampanye Sustainable Seafood adalah media pertemuan dan media internet seperti Twitter dan website WWF. Hal tersebut mengakibatkan responden kategori konsumen terdorong untuk merubah sikap sesuai dengan pesan yang disampaikan.

Penelitian memperlihatkan hubungan antara keterdedahan media dengan efektivitas komunikasi pemasaran sosial. Pada penelitian tersebut terlihat bahwa terdapat hubungan yang kuat antara frekuensi keterdedahan media terhadap aspek kognitif dan konatif pada responden kategori produsen. Hal tersebut disebabkan oleh responden kategori konsumen yang sudah cukup terkena pesan melalui media. Mayoritas media yang digunakan untuk mendapatkan pesan Kampanye Sustainable Seafood adalah media pertemuan. Walaupun mayoritas responden Kampanye Sustainable Seafood mendapatkan pesan mengenai kampanye Sustainable Seafood melalui media pertemuan, seperti pelatihan dan diskusi yang diadakan rutin hampir satu atau dua bulan sekali. Hal tersebut mengakibatkan responden kategori produsen terdorong untuk merubah sikap sesuai dengan pesan yang disampaikan.

\section{SIMPULAN DAN SARAN}

\section{Simpulan}

Strategi komunikasi pemasaran sosial yang digunakan oleh WWF dalam memasarkan Kampanye Sustainable Seafood mayoritas menggunakan media pertemuan, seperti seminar, pameran, diskusi, presentasi, dan gathering meet. Mayoritas responden mendapatkan pesan mengenai Kampanye Sustainable Seafood dari pengurus WWF dan LSM aliansi WWF. Sumber pesan menyampaikan pesan mengenai Kampanye Sustainable Seafood kepada responden menggunakan bahasa yang mudah dipahami dan materi yang disampaikan sesuai dengan tujuan Kampanye Sustainable Seafood yaitu menyelamatkan industri perikanan dari eksploitasi berlebihan.

Efektivitas strategi komunikasi pemasaran sosial dilihat dari aspeka kognitif, afektif, dan konatif. Pada aspek kognitif termasuk dalam kategori tinggi, aspek afektif termasuk dalam kategori sedang, dan aspek konatif termasuk dalam kategori tinggi.

Pada responden kategori konsumen terdapat hubungan kuat antara ragam sumber pesan dengan aspek kognitif dan konatif, terdapat hubungan kuat antara pesan dengan aspek kognitif, terdapat hubungan antara ragam media dan aspek kognitif dan konatif, dan frekuensi keterdedahan media dengan aspek kognitif dan konatif. Sedangkan pada responden kategori produsen terdapat hubungan kuat antara ragam sumber pesan dengan aspek kognitif dan konatif, terdapat hubungan kuat antara pesan dengan aspek kognitif dan konatif, terdapat hubungan antara ragam media dan aspek kognitif, dan frekuensi keterdedahan media dengan aspek kognitif dan konatif.

\section{Saran}

1. Penyelenggara Kampanye Sustainable Seafood yakni WWF sebaiknya mengembangkan komunikasi pemasaran sosial melalui media sosial, seperti Twitter dan Facebook. World Wide Fund for Nature dapat menyajikan data-data terkait perikanan berkelanjutan melalui media sosial dan memperkenalkan Seafood Guide kepada publik.

2. Program-program WWF yang berkaitan dengan Kampanye Sustainable Seafood perlu menyajikan data-data terkini mengenai pentingnya perikanan berkelanjutan dan hidangan laut lestari di media sosial masing-masing program dan menggunakan media jangka panjang seperi papan reklame. 
3. Pelaksanaan komunikasi pemasaran sosial untuk responden kategori produsen sebaiknya menggunakan media yang beragam karena mayoritas responden hanya mendapatkan informasi dari pengurus WWF dan atau pengurus LSM aliansi WWF.

4. Untuk akademisi adalah agar melakukan penelitian lebih lanjut mengenai efektivitas strategi komunikasi pemasaran sosial dan memberi focus pada penggunaan media sosial. Penelitian selanjutnya diharapkan dapat meilihat pengaruh perbedaan perilaku pengunjung terhadap efektivitas strategi komunikasi pemasaran sosial.

\section{DAFTAR PUSTAKA}

KKP (Kementerian Kelautan dan Perikanan). 2013. Statistik Kelautan dan Perikanan 2011. (Internet). (dikutip tanggal 13 Juni 2014). Dapat diunduh dari: http://statistik.kkp.go.id/ index.php/arsip/c/37/Buku-Kelautan-danPerikanan-Dalam-Angka2011/?category_id $=3$

Kotler P, Zaltman. 1981. Social Marketing: An Approach to Planned Social Change. [Internet]. [dikutip tanggal 18 Desember 2014]. Dapat diunduh dari: http://www.sfu.ca/cmns/faculty/laba_m/4 25/07-fall/documents/Kotler-

Zaltman.PDF

Lubis DP. 2009. Pendahuluan. Dalam: Hubies AVS, editor. Dasar-dasar komunikasi. Bogor (ID): Sains Komunikasi dan Pengembangan Masyarakat IPB Press. 392 hal.

Ruslan R. 2005. Kampanye Public Relation. Jakarta (ID): PT Raja Grafindo. 146 hal.

Severin W, Tankard JW. 2005. Teori Komunikasi: Sejarah Metode dan Terapan di dalam Media Massa. Jakarta (ID): Kencana. 488 hal.

Shimp T. 2003. Periklanan Promosi Aspek Tambahan Komunikasi Pemasaran Terpadu Jilid II. Jakarta (ID): Erlangga. 650 hal.

Shimp T. 2003. Periklanan Promosi Aspek Tambahan Komunikasi Pemasaran Terpadu Jilid I. Jakarta (ID): Erlangga. 310 hal.
Singarimbun M dan Effendi S. 2008. Metode penelitian survai. Effendi $\mathrm{S}$, editor. Jakarta (ID): LP3ES.

Tjiptono F. 2008. Strategi pemasaran. Yogyakarta (ID): CV Andi Offset. 588 hal.

Venus A. 2004. Manajemen Kampanye: Panduan Teoretis dan Praktis dalam Mengefektifkan Kampanye Komunikasi. Badung (ID): PT Remaja Rosdakarya Offset. 268 hal. 